\title{
Identity Construction and Ideological Reproduction of the Secondary English Language Textbooks in Bangladesh
}

\author{
Jia Li ${ }^{1}$, Wei Duan ${ }^{1,}$, , Juan Dong ${ }^{1}$, Sagred al Miskat Sharif ${ }^{2}$ \\ ${ }^{1}$ School of Foreign Languages, Yunnan University, Kunming, China \\ ${ }^{2}$ School of International Education, Yunnan University, Kunming, China
}

Email address:

463850849@qq.com (Wei Duan)

${ }^{*}$ Corresponding author

\section{To cite this article:}

Jia Li, Wei Duan, Juan Dong, Sagred al Miskat Sharif. Identity Construction and Ideological Reproduction of the Secondary English Language Textbooks in Bangladesh. International Journal of Language and Linguistics. Vol. 7, No. 6, 2019, pp. 302-314.

doi: $10.11648 /$ j.ij11.20190706.18

Received: October 17, 2019; Accepted: November 5, 2019; Published: November 8, 2019

\begin{abstract}
Foreign language textbooks play an important role in shaping learners' awareness of cultural diversity and ideological orientation. This study evaluates four English textbooks English for Today for Bangladeshi students of Junior Secondary level from Class Six to Class Ten. Data were collected from images, reading passages and dialogues of the textbooks. Following the theory of language ideology, the study examines the identity options and ideological representations in the English textbooks. Findings indicate that there are two different communities constructed by Bangladeshi characters and foreign characters in terms of gender, occupation, ethnicity and nationality; findings reveal that the identity option of Bangladeshi characters is diverse ranging from upper/middle class to low class whereas foreign characters are exclusively constructed as white/Anglophone holding decent jobs and having middle class background. Findings also show that the cultural representation of Bangladesh is dominated by the linguistic nationalism of speaking Bangla and following Bangladeshi practices as cultural norm while othering and even stigmatizing minority cultures. When representing foreign cultural practices, British-centered knowledge is produced as norm and Anglophones as ideal English speakers, and English is constructed as panacea for getting good jobs and communicating with people worldwide. Based on the findings, we argue that the white/Anglophone-centered ideology and homogenous representation of Bangladeshi culture are the reproduction of hierarchical differences structured in the postcolonial regiment. We also argue that highlighting Bangladeshi women's social achievement and minimizing the representation of Muslim practices are mediated in the wider process of socioeconomic transformation of turning Bangladesh into a world factory with sufficient human resources and little religious disturbance. This study has implications for designing foreign language textbooks and it suggests that more diversified practices from source and foreign cultures should be included in the textbooks to cultivate learners' cultural awareness and appreciation of cultural differences on an equal basis.
\end{abstract}

Keywords: English Textbooks, Bangladesh, English, Culture, Ideology

\section{Introduction}

\subsection{Socioeconomic Transformations of Bangladesh}

Bangladesh, officially the People's Republic of Bangladesh, is one of the most densely-populated countries in the world with a total population of exceeding 162 million in an area of $147,570 \mathrm{~km}^{2}$ [41]. Bangladesh was wracked by poverty and famine for many years after its independence in 1971. During its first five years of independence, Bangladesh adopted social policies to develop economy [25]. The subsequent Jatiya Party governments restored free markets and promoted its private sector. In 1991, a programme of economic liberation was introduced to rapidly expand private sector with a number of conglomerates driving the economy. In recent years, Bangladesh has gone from being one of the poorest countries in South Asia to an aspiring "tiger" economy [7]. This economic transformation is largely driven by its success of manufacturing industry $[1,47,52]$. It mainly includes jute, textile, garment and food industry, etc. Jute industry is the largest industry in Bangladesh. Due to its suitable natural conditions for growth of jute, Bangladesh now is the world's 
largest jute producer. The textile and ready-made garment industries are the second largest manufacturing sector and the export income reached 7.9 billion dollars in 2006 [33]. The increase of manufacturing industry provides employment for more than 2.2 million people with the empowerment of women labours [25].

As the industry is highly labour-intensive in nature, lower wage rate countries were always the major supplier in the world. It is held that cheap and readily employable labour of Bangladesh underpins the competitive advantage of the country's mass production and competitive prices for foreign buyers, competing directly with countries such as China, India and Vietnam [52]. Garments are mainly exported to the United States of America and European countries [25]. Female workers contribute a lot to mass production of garment industry in Bangladesh. In garment production, according to 2005 labour force survey, female workers constitute more than 60 percent of total force because women entering the industrial labour force in Bangladesh generally find themselves in low skill or low wage jobs $[3,46]$.

\subsection{Language Policy of Bangladesh}

Language policy (LP) is stated explicitly through official documents such as national laws, declaration of certain languages as "official" or "national", language standards, curricula, and other types of documents. In other contexts, language policy is not stated explicitly, but can be derived implicitly from examining a variety of de facto practices [44]. In the specific contexts of education, there is language education policy (LEP) carrying out LP decisions as a form of manipulation of language policy in educational institutions in relation to home languages and to foreign and second languages. LEP as part of LP is also stated implicitly by examining a variety of practices. The implicit situations make LEP more difficult to detect as it is hidden from the public eye. It is in these situations that LEP needs to be derived from actual language practices through the study of textbooks, teaching practices and testing systems [44].

In Bangladesh, the majority of the population are Bengalis speaking Bangla [41]. The first Constitution in Part 1 Article 3, declared that the state language of the Republic is Bangla [15]. Bangladeshi government attaches great importance to the development and promotion of Bengali language. As the national language of Bangladesh, its status is the indestructible because it is a symbol of national identity and national unity. However, English, the global language, enjoys a special status in Bangladesh. English developed in Bangladesh through British colonial rule [17]. Although Bangladesh currently has been freed from the British colonization, due to historical reasons and the prominent role of English in economic globalization, English has exerted a profound influence and has penetrated into Bangladeshi society, that is, English is widely used in government departments, industrial, commercial, intellectual and medical fields, and educational institutions [25]. It is obvious that LEP in Bangladesh emphasizes the English learning in schools and universities. Therefore, it is of great importance to explore
EFL classroom within which English textbooks are the hidden education policy.

\subsection{Research Gap and Research Questions}

Many studies have been conducted to investigate identity constructions represented in language textbooks in different contexts like China [29], Iran [4], Saudi Arabia [2] and Russia [45]. As for ELT textbook research in Bangladesh, there are some scholars analysing the application of English textbooks in higher secondary level. To our best knowledge, no research has yet been conducted on ideological representations in English language textbooks in Junior Secondary level in Bangladesh. While Bangladesh is turning itself into a world factory, it is of significance how Bangladesh sees the values of English and how learning English might shape Bangladeshi youth's global vision and intercultural awareness. Aligned with this inquiry, this study aims at filling the gap by evaluating English language textbooks used in Bangladesh in Junior Secondary level by exploring two research questions:

1) What are identity options of Bangladeshi and foreign characters produced in English for Today textbooks in junior secondary level?

2) What ideologies are represented in the source and target culture?

\section{Literature Review}

\subsection{Identity Options in Language Textbooks}

The study of identity construction in foreign language (FL) and L2 textbooks has emerged as one of the popular topics in applied linguistics [45]. Many studies conducted in different contexts have shown that foreign language textbooks have not provided learners with a broad range of identity options. In Saudi Arabia, English textbooks do not include women as legitimate member for social participation [2]. Early studies concentrated on the sexism in FL and L2 textbooks in the 1980s Porreca, in 1984, analyzed 15 English textbooks used in the United States, focusing on gender representations in images, texts, noun frequency, and character sequence and finding sexism presented in textbooks [37]. The subsequent analyses significantly proved that textbooks implicitly continued to reproduce sex biases. Canagarajah, in 1993, examined a U.S.-published ESL textbook applied in Sri Lanka and exposed the implicit ideological values conveyed by the text, that is, racial and gender biases exhibited in the hidden curriculum [11] Siegal and Okamoto, in 1996, revealed that Japanese textbooks oriented at American students expressed linguistic stereotypes based on hegemonic ideologies of gender and class [48]. In 1997, Poulou explored Greek textbooks and found that male possessed more powerful discursive role in gender relations [38]. In $21^{\text {st }}$ century, many scholars have attempted to expand the focus of inquiry and ranges of identities. Textbooks are continuously considered to reproduce gender biases by assigning the stereotypical role of women as mothers and homemakers. In 2003, Otlowski criticised textbooks contributing to the misinterpretation of women and minority 
groups [34]. The original image of women as homemakers seemed to contradict with a new role in the work force in many developed countries. In a more recent study, EFL textbooks were investigated, focusing on the linguistic representation and construction of male and female social identities. Findings concluded that apparent attempts have been made to bring women from marginalized status to the foreground in this series. This highlighted representation of females challenges traditional values that demean the value of women in society. Women are as crucial as men to the functions of the communities [43]. In another study, Söylemez, in 2010, exemplified the construction of social gender identity in the reading passages in two sets of textbooks. The adjectives to describe genders were identified and categorized to determine characteristics of male and female and to construct their social identities. Results indicated that the adjectives chosen randomly reflected the biased tendency to use some adjectives to depict one gender rather than the other [50].

In some other studies, the focus of inquiry is expanded to the oversimplified identity options to FL learners in language textbooks. Alimorad, in 2014, evaluated identity options in two English textbooks series taught in Iran, Right Path to English (RPE) and Cambridge English for Schools (CES). Findings indicated that RPE provides its readers with a limited range of identities and an ethnically homogenous imaginary world of English use. CES, on the other hand, introduces a wider range of identity options and depicts a more varied and ethnically heterogeneous picture of English use [4]. In the study of English language textbooks used in Saudi Arabic, in 2017, Alshammri examined gender, occupational identities, ethnicity and religious affiliation of Saudi and foreign characters. It revealed that the representation of Saudi characters is accurate in terms of identity options but there is oversimplification and imbalance in the representations of foreign characters [2].

In the context of Bangladesh, some studies on English textbooks evaluation have been conducted. Ali, in 2014, evaluates the ELT textbook English for Today for classes 11-12 of Higher Secondary Education (HSE) level to examine whether any inconsistencies exist between the external claims made for the textbook in relation to the goal of the national ELT curriculum and the overall internal organisation of the book by using the McDonough \& Shaw model. Results indicated a mismatch between the overall goal of the HSE level ELT curriculum and the way the textbook has been designed [5]. The ELT textbook English for Today for classes 11-12 of Higher Secondary Education (HSE) level is also examined in terms of the application of the English textbook and effectiveness for language teaching and learning [18]. The study revealed that almost all teachers and students agree that the text is rich enough for acquiring all four language skills, but their learning and teaching activities are rather examination-oriented than acquiring language competency.

\subsection{Ideology in Language Textbooks}

Language ideology refers to the perceptions held by people about a specific language or language in general. Silverstein in
1979, defined language ideologies as "any sets of beliefs about language articulated by the users as a rationalization or justification of perceived language structure and use" [49]. These beliefs include, for example, ideas about the status of specific languages, the appropriateness or inappropriateness of some expressions in particular contexts, and how language should be taught to children. Because the beliefs about language, or language ideologies are 'constructed from the sociocultural experience of the speaker' [23]. Thus, language ideologies are multiple, diverse and dynamic because language ideologies as beliefs, feelings, and conceptions about language that are socially shared and relate language and society in a dialectical fashion [35]. Piller, in 2015, illustrated that language ideologies undergird language use, which in turn shapes language ideologies; and they serve social ends.

Language is a material form of ideology, and language in invested by ideology [13]. In this sense, ideology and language learning in education is closely related with each other. Apple, in 1990, states that ideology in language textbooks is promoted through the manipulation of knowledge [6]. This manipulation may be appeared in different texts and in images and may have positive or negative impacts or both [28]. Therefore, language textbooks are not only an important source for conveying subject knowledge but also an important source for conveying potential beliefs and principles underlying knowledge [2].

Nationalism is quite explicit in language textbooks. In many non-English speaking countries where English is taught as a foreign language, various policies and discourses have been adopted to develop a strong sense of national identities as resistance to global hegemony of English [31]. National cultures are primary source of national identities [19]. So in those contexts, there is a focus on promotion of local cultures in ELT and English language textbooks [21]. In most cases, the learning content of English textbooks is primarily devoted to local culture. In the study of cultural representations of Chinese primary English textbooks, in 2011, it is revealed that the promotion of Chinese culture in the textbooks has been used to cultivate student's strong sense of national pride and to foster Chinese national identity [29]. The construction of nationalism embedded in those textbooks clearly reflects ideological concerns in the curriculum discourse in which English language teaching has been utilised to resist the hegemonic effects of English.

Essentialism is considered as a kind of ideology. When it comes to society, it is no surprise that the social aspects of essentialism have received a great deal of attention [8]. Social essentialism entails the belief that certain social categories like gender or race mark fundamentally distinct kinds of people" [42]. Indeed, it is on the social categories of language, culture, race $[14,51]$ and gender $[39,40]$. In the field of language, most countries adopt "one nation, one language" ideology which is the belief of monolingualism is important for social harmony and national unity [35]. In the USA, for instance, the belief is widespread that "Standard American English" is the only appropriate medium for use in education, public 
administration, employment, the courts, or the media [26]. By contrast, other forms of language such as African American English, Southern English, or Spanish are considered inappropriate for these purposes [35]. This essentialism is also prevalent in language learning in most countries.

From the aforementioned literature, none of studies has provided a comprehensive examination of identity options and potential ideologies represented in Bangladeshi EFL textbooks in Junior Secondary level. Therefore, in order to fill this gap, the study tends to explore identity options and ideological representations in English textbooks, English for Today from Class Six to Ten used in Junior Secondary level.

\section{Methodology}

\subsection{Data Selection and Description}

In this study, the reasons why English for Today textbooks in Junior Secondary Public Schools in general education system are as follows.

Based on 2010 National Education Policy [27], there are three main educational systems in Bangladesh: General Education System, Madrasa Education System and Technical and Vocational Education System. The General Education System and Madrasa Education System are comparatively divided into three levels, primary, secondary and tertiary levels. Primary education includes Classes 1 to 5 . Secondary education is sub-divided into Junior Secondary (Class 6 to 10) and Higher Secondary (Class 11 to 12) and tertiary education goes to universities. According to the statistic of Ministry of Education in Bangladesh, up to 2018, the number of students who go to general schools is the most compared with religious schools and vocational training. So this study focuses on general education.

In general education system, students can choose to Bangla-medium or English-medium schools. Since Bangla-medium schools are government-sponsored, most students choose to have education there. English-medium schools are private and only a few students can afford the high tuition fee. Concerning the universality, public schools in general education system are the most suitable for the study.

When it comes to English subject, English for Today (EFT) is a prescribed book of English language for every student of Bangladesh up to Higher Secondary level [18]. This series is authoritative because it is designed by National Curriculum and Textbook Board. According to National Education Policy-2010, National Curriculum and Textbook Board is responsible to design the uniform curriculum and prepare necessary textbooks for every stream at secondary level. In addition, English language is set as a compulsory subject adopted in all streams from the secondary level. Therefore, evaluating English textbooks for Junior Secondary schools (Class 6 to 10) is suitable because of the great importance and depth of learning English at this stage.

There are four English textbooks used in Junior Secondary level, Class Six, Class Seven, Class Eight, Class Nine and Ten sharing one book. Class Six consists of 35 lessons, 9 units in Class Seven, 9 units in Class Eight and 14 units in Class Nine and Ten. The curriculum makes makes the language learning contents graded and explicitly reflect real life situations. The English for Today textbooks are designed to help students attain competency in all four language skills, i.e. listening, speaking, reading and writing. These units contain a number of listening texts and reading passages as well as dialogues and conversation practices. In addition, writing exercises of different topics are conducted to develop students' writing abilities.

\subsection{Data Analyzing Method}

Content analysis is applied in this study for dealing with different types of English learning materials in the textbooks and finding out the potential identities and ideologies emerging from these data. Content analysis has been broadly defined as "any technique for making inference by objectively and systemically identifying specified characteristics of messages" [20]. It is one of the extensively used analysis methods in language studies. Previous scholars doing multilingual studies $[16,24]$ have used this method to analyze the emerging themes from the data in explicit and implicit ways. This method allows researchers to identify general themes and to generalise specific themes after interactively data coding and in-depth analysis.

Thematic analysis is also applied in this study. Thematic analysis is the process of identifying patterns or themes within qualitative data. It is stated that it provides core skills that will be useful for conducting many other kinds of analysis [9]. A further advantage in terms of learning and teaching is that it is a method rather than a methodology [10]. This means that, unlike many qualitative methodologies, it is not tied to a particular epistemological or theoretical perspective [30]. This makes it a very flexible method, a considerable advantage given the diversity of work in learning and teaching. Typically, this reflects the fact that the data have been summarised and organised, rather than analysed. Content and thematic analysis methods are interactively cooperated to evaluate and reveal identities and ideologies in the English language textbooks.

\section{Findings}

\subsection{Identity Options in the Textbooks}

\subsubsection{Characters from the Source and Target Culture}

Table 1. Character distribution for the Class 6 to 10 of English for Today textbooks.

\begin{tabular}{lll}
\hline Types of Characters & $\begin{array}{l}\text { Bangladeshi } \\
\text { characters }\end{array}$ & Foreign characters \\
\hline Number & 180 & 31 \\
Percentage & $85.3 \%$ & $14.7 \%$ \\
\hline
\end{tabular}

Table 1 shows that there are 211 characters in the textbooks, 180 Bangladeshi characters and 31 foreign characters. It is clear that the representation of Bangladeshi characters $(85.3 \%)$ is quite prominent whereas the foreign characters are under-represented with only $14.7 \%$. 


\subsubsection{Gender}

Table 2. Gender distribution for the Class 6 to 10 of English for Today textbooks.

\begin{tabular}{lllll}
\hline Nationality and gender & Bangladeshi Male & Bangladeshi female & Foreign male & Foreign female \\
\hline Number & 118 & 62 & 19 & 12 \\
Percentage & $55.9 \%$ & $29.4 \%$ & $9 \%$ & $5.7 \%$ \\
\hline
\end{tabular}

Table 2 presents the number of male and female of characters for Bangladesh and foreign countries. The number of Bangladeshi male characters (118) is almost two times than

that of female characters (62). The unequal distribution is also found among the foreign characters.

\subsubsection{Occupation}

Table 3. Occupations of Characters for the Class 6 to 10 of English for Today textbooks.

\begin{tabular}{|c|c|c|c|c|c|}
\hline \multirow{2}{*}{$\begin{array}{l}\text { Bangladeshi characters } \\
\text { Occupations }\end{array}$} & \multirow[b]{2}{*}{ Male } & \multirow[b]{2}{*}{ Female } & \multicolumn{2}{|c|}{ Foreign characters } & \multirow[b]{2}{*}{ Female } \\
\hline & & & Occupations & Male & \\
\hline Student & 62 & 28 & Poet & 8 & 6 \\
\hline Teacher & 5 & 9 & Author & 2 & 2 \\
\hline Singer & 1 & - & Student & 1 & 2 \\
\hline Officer & 3 & 1 & accountant & 1 & - \\
\hline Architect & - & 1 & Singer & 1 & - \\
\hline Pilot & 1 & - & humanitarian & - & 1 \\
\hline Doctor & 4 & - & Olympian & 2 & - \\
\hline Lawyer & - & 1 & Nurse & - & 1 \\
\hline Newspaper hawker & 1 & - & Footballer & 2 & - \\
\hline Rickshaw-puller & 1 & - & Volunteer & 1 & - \\
\hline Waiter & 1 & - & Undefined & 1 & - \\
\hline Waitress & - & 1 & & & \\
\hline Cleaner & 1 & - & & & \\
\hline Postman & 1 & - & & & \\
\hline Nurse & - & 1 & & & \\
\hline Rubbish collector & 1 & - & & & \\
\hline Salesman & 2 & - & & & \\
\hline Pharmacist & 1 & - & & & \\
\hline Mystic bards & 3 & - & & & \\
\hline Soldier & 2 & - & & & \\
\hline Footballer & 2 & - & & & \\
\hline Shooter & - & 3 & & & \\
\hline Carpenter & 1 & - & & & \\
\hline Homemaker & & 1 & & & \\
\hline Reporter & 1 & 1 & & & \\
\hline Social worker & - & 1 & & & \\
\hline NGO worker & 1 & - & & & \\
\hline Boutique owner & - & 1 & & & \\
\hline Hair dresser & 1 & - & & & \\
\hline Director & 1 & - & & & \\
\hline Captain & 1 & - & & & \\
\hline Entrepreneur & 1 & - & & & \\
\hline Garment worker & - & 1 & & & \\
\hline Film maker & 1 & - & & & \\
\hline Scientist & 1 & - & & & \\
\hline Farmer & 1 & - & & & \\
\hline Poet & 1 & - & & & \\
\hline Artist & 1 & - & & & \\
\hline TV anchor & 1 & - & & & \\
\hline Mime actor & 1 & - & & & \\
\hline Undefined & 12 & 12 & & & \\
\hline
\end{tabular}

Table 3 illustrates the occupations of the Bangladeshi and foreign characters represented in English for Today textbooks of Class Six to Ten. There are 40 occupations assigned to Bangladeshi characters and 10 occupations to foreign ones. Among Bangladeshi characters, the occupational distribution almost covers all social classes ranging from doctor and lawyer to farmer and rubbish collector. In terms of gender, Bangladeshi male characters constitute more occupations than female characters. It is noted that despite having less number of jobs, females are represented in the textbooks with powerful working backgrounds such as working as lawyer, shooter, architect etc. Regarding the occupational positions of 
foreign characters, the total number is extremely low. Besides, the occupational range of foreign characters is comparatively narrow with only a few occupations represented. However, concerning the job positions available to foreign characters, foreigners seem to hold decent jobs with middle class background and no one is taking up any low-class jobs. We argue that such representation of constructing foreigners exclusively as powerful and socially respectful would create "colonial cringe" or "inferiority complex" [36] among the language learners, namely Bangladeshi teenagers.

\subsubsection{Ethnicity and Nationality}

The ethnic identities of characters in the textbooks are defined based on their general appearance shown through images and linguistic clues from the description of written and spoken texts. The majority of Bangladeshi characters represented in English for Today textbooks can be described as local Bengalis. A few ethnic groups are also appeared in the textbooks. This majority representation of Bangladeshi characters is likely typical and accurate for reflecting broad ranges of ethnicities within Bangladesh context.

In terms of foreign aspects in English for Today textbooks from Class Six to Ten, the main male and female characters are British. The detailed distribution of foreign male and female characters on ethnicity and nationality is indicated in Table 4 .

Table 4. Ethnicity, nationality and gender of foreign characters.

\begin{tabular}{llll}
\hline ethnicity & Nationality & male & female \\
\hline \multirow{4}{*}{ White } & British & 10 & 7 \\
& Australian & 1 & - \\
& American & 4 & 2 \\
& Argentina & 1 & - \\
\multirow{3}{*}{ Black } & Irish & - & 1 \\
& Undefined & 2 & 1 \\
& African American & - & 1 \\
\hline
\end{tabular}

From Table 4, foreign characters represented in the English for Today textbooks are almost "White" and "British". Although a few other national identity options for English learners are depicted, it is still Anglophone-centered. It is clear that the diversity of English speakers has been oversimplified. This imbalanced representation of foreign characters indicates a linguistic and racial hierarchy with White British English speakers as desirable targeting interlocutors for Bangladeshi students. Such unbalanced distribution of foreign countries does not only reproduce the Anglophone-centered world but also marginalize the cultural diversity of other countries.

\subsection{Cultural Representations}

\subsubsection{Nationalism}

Bangladesh is a country where the national events of Language Movement and the Liberation War are highlighted as national pride. The Bangla Language Movement is constructed as a political movement advocating the recognition of the Bangla language as an official language against Urdu language under the rule of Dominion of Pakistan for the continuation of its use in government affairs, and medium of education from 1948 to 1952 . The movement resulted in gaining the official status to the Bangla language. The Language Movement became the forerunner to Bangladesh Liberation War. Bangladesh War of Independence or Liberation War refers to as an armed conflict between West Pakistan (now Pakistan) and East Pakistan (now Bangladesh) that lasted for almost nine months in 1971. The war ended with the independence from Pakistan. In 1999 UNESCO declared 21 February as International Mother Language Day in memory of the Language Movement and the fighting for linguistic rights of people around the world. Therefore, in the textbooks, the national language status of Bangla language from Language Movement and spirit of national independence from Liberation War are highlighted.

\section{i. Speaking Bangla for showing National patriotism}

21 February is a memorable day in our national history. We observe the day every year as International Mother Language Day. On this day, we pay tribute to the martyrs who laid down their lives to establish Bangla as a state language in undivided Pakistan in 1952. The struggle to achieve our language rights is known as the Language Movement...

The UNESCO (United Nations Educational, Scientific and Cultural Organisation) on 17 November in 1999 proclaimed February 21 as the International Mother Language Day in recognition of the sacrifices of the martyrs for the rightful place of Bangla. The day is now annually observed worldwide to promote awareness of linguistic and cultural diversity and multilingualism.

Excerpt 1. Language Movement (English for Today, Class 9 and 10, p. 33)

In the textbooks, learning English includes the national memory of Language Movement in history. In the excerpt 1, there is a description of the historical event on how Bangladeshi people used to fight for their "language right" by speaking Bangla as the national language, such movement was considered as the "supreme sacrifices of our language martyrs". The first person plural noun "our" is used to represent the national ideology of speaking Bangla for loving the country, which is the reproduction of the one-nation-one-language ideology. Such linguistic nationalism is legitimized as mother tongue, "language right", acknowledged by the international organization-UNESCO for the justification of multilingual diversity. However, it is questionable when it comes to over 30 languages used and spoken by Bangladeshi people of diverse backgrounds.

ii. Speaking Bangla as resistance against former Pakistan regime

For the people of Bangladesh, March is a month of unforgettable memories of pride as well as of sorrow and grief. It is a moth of proud memories because in this moth in 1971 Bangabandhu Sheikh Mujibur Rahman declared the Independence of Bangladesh...

But March is also a month of sad memories for us. On the $25^{\text {th }}$ March 1971, the Pakistani army swooped upon the Bangalees. They killed many unarmed and innocent men, women and children in Dhaka. The Bangalees started 
resisting Pakistani army and the war of liberation began. On the $16^{\text {th }}$ December of the same year, a new nation independent Bangladesh was born...

Excerpt 2. Independence of Bangladesh (English for Today, Class 6, P. 46)

Apart from showing their national patriotism, the value of speaking Bangla also indicates Bangladeshi people's resistance against their former colonizer-Pakistan. In the excerpt 2 , textbook Class Six, the national collective memory about the War of Independence against Pakistan has been constructed. To reinforce the national identity, Pakistani soldiers are depicted as ruthless devils killing "unarmed and innocent men, women and children" in the capital city of Bangladesh. Thus the foreign country Pakistan has been constructed as"the imagined enemy" in the textbooks among Bangladeshi youth. It is questionable whether such "sad memory" would create further conflicts rather than bridging the communication gaps between Bangladeshi and Pakistani young people.

\subsubsection{The Dominant Impacts of English}

The English for Today textbooks highlight the values of learning English in travelling globally, getting decent jobs, and communicating with other foreigners as lingua franca as described below.

i. English as a necessity for travelling outside Bangladesh

In textbook of Class 8, unit 6 "Going on a Foreign Trip" typically illustrates that English is a necessity for travelling outside Bangladesh. The following figures 1 and 2 highlight the significance of using English for international communication crossing the national boundary. This foreign trip is to Bangkok, Thailand. The Tha Kha floating market and the Tha Kha river are introduced in the textbook.
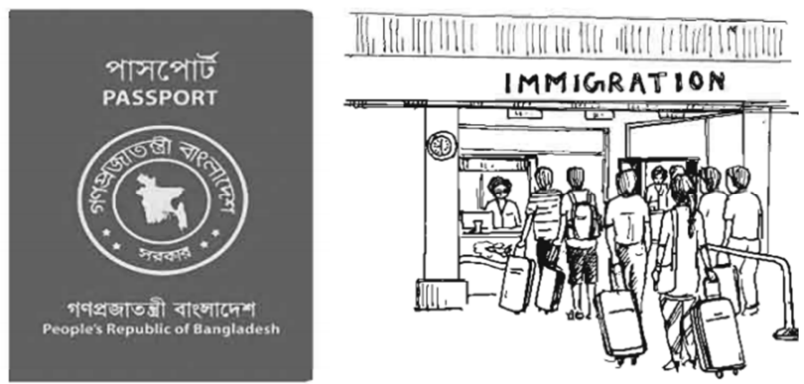

Figure 1. English used in global travelling (English for Today, Class 8, P. 63).

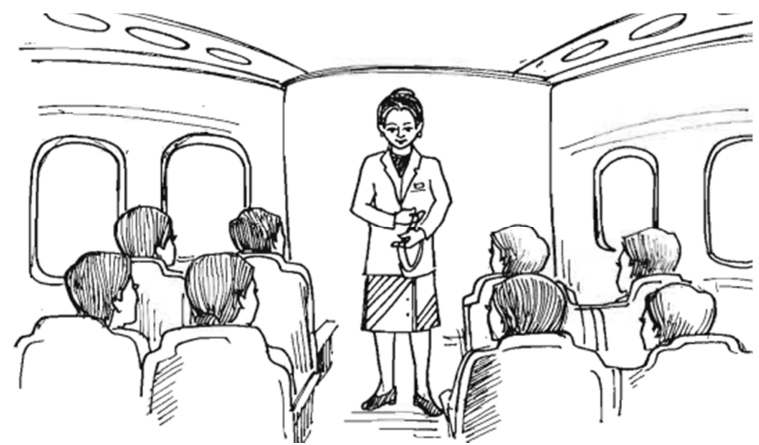

Figure 2. Practical English on announcements in planes (English for Today, Class 8, P. 69).
Despite the fact that both Bangladesh and Thailand do not speak English as national language, the cross-cultural communication between these two countries are simultaneously conducted in English. Besides, the people depicted in the above figures seem to show no disagreement on choosing English as a default lingua franca and they all seem to be competent English speakers without any communication barrier. Such "safe" and "easy" communication with English is in stark contrast to many studies conducted in non-English speaking contexts where people who speak English with various accents find themselves unable to understand each other effectively and some social stereotypes also emerge because of their preferred accent [22, 32].

ii. English as the only lingua franca for global communication

There are many countries in the world with many languages, but to communicate with them, you cannot use all the languages. So you need a common language that you can use with more or less all the people in the world. English is that common language. We can communicate with the whole world easily. English has made this communication easier."

Excerpt 3. English as lingua franca (English for Today, Class 9 and 10, P. 53)

The state of English as lingua franca is reinforced in the textbooks. Based on the excerpt 3, English language builds a conversational bridge among people from different countries with diversified linguistic backgrounds. It seems that people whose mother tongue is different can express themselves and understand each other in English.

iii. English as a panacea getting good jobs

In the textbooks, English is described as a language bridge which can link people to the whole world. Such global status has been reinforced by the description that English can function more effectively than other international languages such as "Chinese", "Korean" and "Arabic". In the page of 53, textbook Class 9 and 10, it is clearly stated that, "You can talk to a Chinese toy maker, a French artist, an Arab ambassador or a Korean builder in ONE language-ENGLIHSH... English for us in Bangladesh is all the more important. As we have sent earlier, we are too many people in a small country. So if you learn English, you have the BEST opportunity to find a GOOD job, both within and outside country. And that is a good news for millions of our unemployed youths".

Perhaps, what makes English most powerful and significant is that English is constructed as a panacea for Bangladeshi youth to get a good job. We have capitalized the modifiers to indicate how learning English is ideologically constructed as "good news" to access to good jobs in a poverty-driven and densely populated country. However, it is still questionable whether any learner might have the same access to English learning resources and become a proficient English speakers and whether acquiring a good English proficiency might transfer to a good job successfully.

iv. Anglophones as ideal English speakers

English speakers are dominantly represented by those from UK, USA and Australia etc. In particular, British people are 
most desirable speakers for English communication. As the following figures 3 and 4 indicate, Anglophone people with Anglophone names are constructed as norm for English communication in various social occasions.

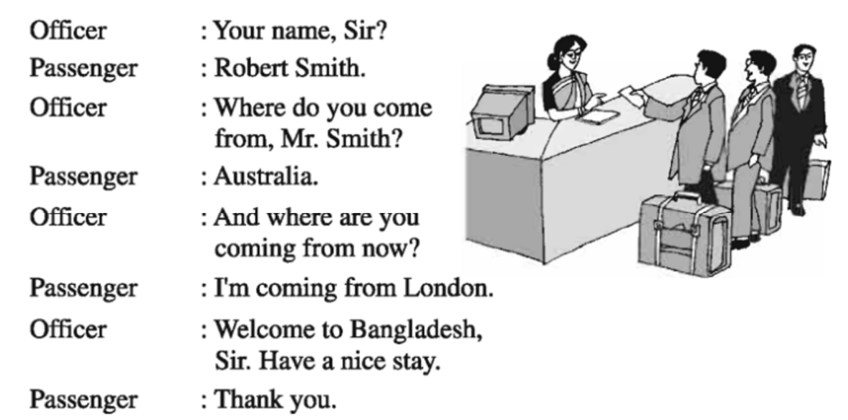

Figure 3. Conversation in English in immigration office (English for Today, Class 6, P. 10).

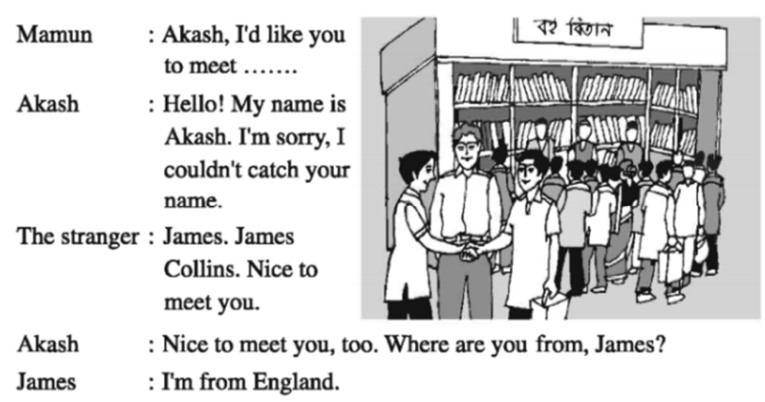

Figure 4. Conversation in English in bookstore (English for Today, Class 6, $p$. 9).

\subsubsection{British-oriented English Education}

In the four textbooks, English-related knowledge like poems and stories is mainly UK-oriented. There are many poems written by British poets among which Figure 5 is one example.

\section{Leisure}

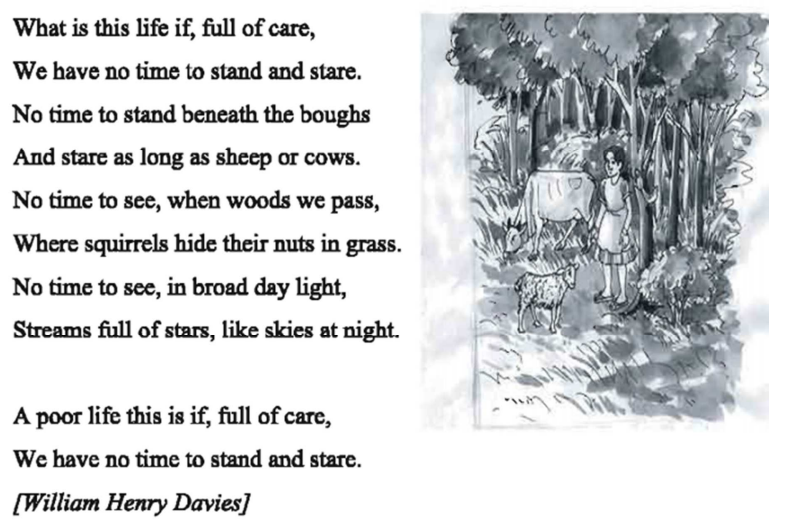

Figure 5. One example of English poem (English for Today, Class 7, P. 55).

Besides, British English is constructed as norm of correctness. This can be indicated in one of the chapters describing how to use the dictionary to look up English word, Oxford dictionary is chosen for explanation in the page of 37 , textbook of Class 8. This is also one example to illustrate the British-oriented English learning.

\subsubsection{Bangladeshi Women with Rising Status}

Despite the imbalanced gender distribution in the textbooks, females are positively constructed. One of the examples in the excerpt 4 is associated with the acknowledgement of their housework.

"What do you do the whole day at home? I work and earn money to run the family. You can't even cook my meals in time!"

"I don't earn money, but I also run the family. I do all the work at home-cooking, cleaning, washing, husking, taking care of the children-everthing," said Nazma. "Remember, you work for money but my work in the home can make the family stick together and make it happy. So both types of work are equally important."

Never before has joynul thought about these things. He feels guilty. Never before has he looked at Nazma with so much admiration and gratitude.

Excerpt 4. Respect to female as a homemaker (English for Today, Class 7, P. 37)

Another positive construction of women in the excerpt 5 can be found in Shahana's story in which she is depicted as able to learn, good at teaching and gaining respect and love from her students, her school and her community.

Shahana's husband Mr. Zamil Huda works in a company office. His firm has a vacant position. On several days he told Shahana, "I want to to apply for the post." But Shahana said, "Please don't insist. I'm joining the local high school as a teacher." "what do you find in a teaching job, Shahana? I don't want you to do it". Her in-laws were also on his side. Yet Shahana joined the school against the will of the family.

Weeks, months went by. Every day Shahana helps with the household work. Every day she works hard to prepare her lessons. Every day she goes to school, teaches her students and helps both weak and bright ones. They often come to her in the teachers' room, in the corridor and even on the road, and talk to her about any academic or personal problems.

Within a year Shahana becomes a very good teacher. Students give her salam wherever they see her. Teachers, even the Head Teacher, admire her. Parents and other people in the community come to see her at home and at school and pay her great respect. One day her husband said, "You've opened my eyes, Shahana. Teaching is more than a job. I didn't know it. Congratulations!" "Thank you," she smiled. "Tell me Shahana, how you could be such a great teacher!" Zamil wanted to know. "I don't only teach my subject. I care for my students. I love them. I myself demonstrate good behaviour and inspire them to be good. That's all I do, " replied Shahana.

Excerpt 5. Insistence of Shahana against her husband (English for Today, Class 7, P. 28)

A third type of positive production of women is how they can change their destiny by working independently and contributing to the local society.

In the textbook Class 8, there is a unit "Making a difference". The whole unit is about the story of a successful female named Shamima Maya. The female character in figure 6 , Shamima, is arranged and forced by her father to marry a man who is greedy and abuses her verbally and physically. 
After her marriage, she cannot tolerate the misery and leaves her husband bravely. Then she designs fabrics and makes block-print, brush-paint and hand-embroidered saris. And she makes dresses for women and fatuas for men. She sells these products in her shop. Now she is the owner of a boutique. She also trains 43 female and provides work for the helpless people. She wants them can live with self-respect and dignity. Shamima fully makes a great difference in her village. Shamima's story is extraordinary in Bangladesh society. It directly reflects that women benefit from the rapid development of manufacturing industry in Bangladesh.

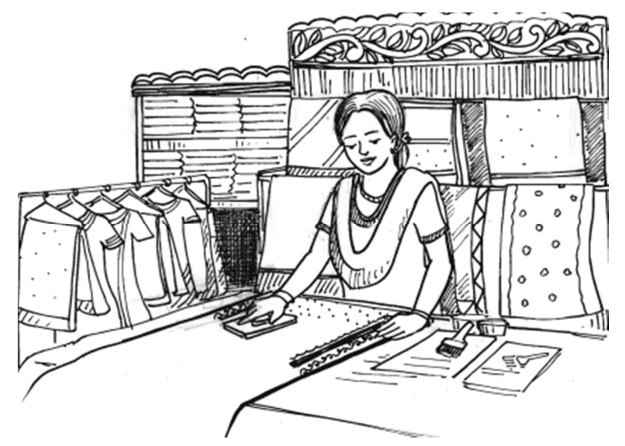

Figure 6. Shamima Maya runs a boutique (English for Today, Class 8, P. 45).

The stories described above are based on grassroots experiences. There are also descriptions about how real women could achieve wonder in their expertise. In the textbook for the Class 7, there is a chapter exploring the "Great women to remember". In the page of 45, a great female historical figure is represented. Begum Rokeya (1880-1932) was a famous Bangladeshi writer and social worker. During her life, she believed that women should have the same rights and opportunities as men have in the society. She fought for equal rights of women. We argue that having described Rokeya's real story in the textbook, there seems to emerge a social transformation on valuing women's role in traditional Muslim countries like Bangladesh. However, if we consider the possibility of how women might fit into the present Bangladeshi market while still sticking onto their traditional family roles, it is still questionable how far such feminist movement might go and whether there might be some tensions both at home and outside.

Apart from the historical figures, modern women in Figure 7 are constructed as physically able to bring glory to the country.

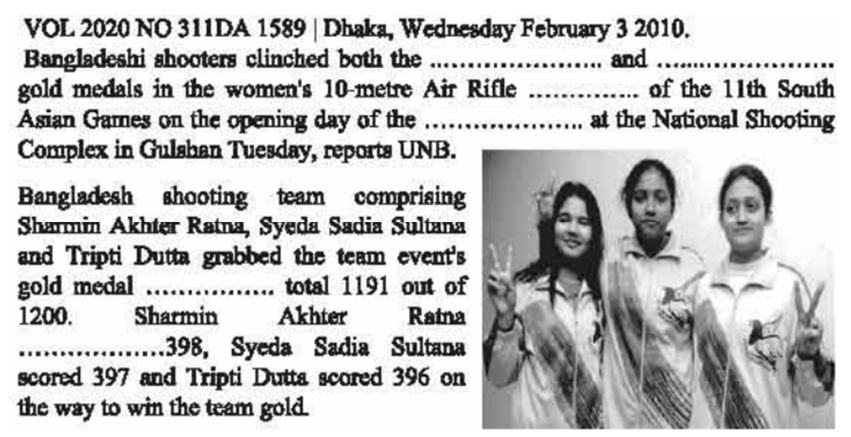

Figure 7. Three Bangladeshi female shooters winning gold (Class 7, P. 81).
What makes such representation most interesting is that women can shape the national image and increase the regional impact of Bangladesh in South Asia.

\subsubsection{Bengali as Essentialized Cultural Practices}

Despite the fact that Bangladesh is an ethnically diversified country [41], there is imbalanced representation of cultural diversity. Bengali, the dominant group with $98 \%$ of the population, is constructed as essentialized token representing the national culture. For example, in Unit 1 of Class 8 "A glimpse of our culture", folk songs, some Bangladeshi musical instruments, Nakshi Kantha, a kind of embroidered quilt are produced in the textbook.

We have a rich history and collection of folk songs in Bangladesh. Of them Palligiti, Bhatiali, Bhawaiya, Jari, Sari, Gambhira, Lalongiti, Palagaan and songs of Hason Raja are very popular. The traditional musical instruments are usually played with these songs.

Excerpt 6. Folk songs (English for Today, Class 8, P. 2)

By using the first person plural forms "we", the folk songs shown in the excerpt 6 are exact and definite representations of Bengali culture. The mystic bard, Hason Raja in this text is a representative standing for Bengali culture. His songs were always popular in Bangladesh and spread all the country. In addition, in the page of 2, textbook Class 8, some local Bengali musical instruments like dotara, tabla, ek-tara and sarinda are appeared frequently in this unit.

Nakshi Kantha is a kind of embroidered quilt. The name was taken from the Bengali word, "naksha" which means artistic pattern. It is a kind of traditional craft and is siad to be indigenous to Bangladesh and West Bengal in India. The art has been practised in rural Bengal for centuries. The name "Nakshi Kantha" became popular after the poet Jasimuddin's poem "Nakshi Kanthar Math" was published in 1929.

Excerpt 7. Nakshi Kantha (English for Today, Class 8, p. 3)

Excerpt 7 is the representation of Nakshi Kantha. It is a Bengali traditional craft. It is said to be indigenous to Bangladesh. It has a long history of being popular since 1929. Nakshi Kantha is made for family use to make quilts. Now the quilts are in great demand and prevalent in Bangladesh.

\subsubsection{Simplification and Otherization of Minority Groups}

In Bangladesh there are more than 30 ethnic groups who have their own languages. A close examination of the textbooks on the representation of non-Bengali culture indicates that these minority cultures are oversimplified and othered with less social prestige.

Most of these ethnic people living in Bangladesh have some common characteristics. They have their own lifestyles. They build their houses on bamboo or wooden platforms called "machang". Rice is their staple food. They eat vegetables, maize and fish, poultry and meat. Their kitchen utensils are bamboo, wooden and earthen pots which they make themselves. Men wear lungis and women wear thamis or sarongs and angis. Women weave their own clothes.

Excerpt 8. Introduction of ethnic people in Bangladesh (English for Today, Class 8, P. 6)

The ethnic people in Bangladesh hold a very important 
place in the culture of the country. The majority of these people live in the Chittagong Hill Tracts. The others live in the regions of Mymensingh, Rajshahi and Sylhet. They live in forest areas, in the hills and in rural areas. They do Jhum cultivation. For this work they clear a piece of land in the forest, prepare it and sow seeds in it. They are mostly farmers. By religion they are Hindus, Christians or Buddhists. They speak their own mother tongues. Some of them are the Chakmas, the Marmans, the Tipperas and the Moorangs, who live in the Hill Tracts. The Santals live in Rajshahi. The Khasias and the Monipuries, live in Sylhet and the Hajangs and the Garos in Mymensingh.

Excerpt 9. Introduction of ethnic people in Bangladesh (English for Today, Class 8, P. 5)

According to the description, other minority groups are homogenized as having "common characteristics", living in mountainous areas, isolated from urban landscapes, working as farmers doing traditional lowly-skilled work. These minority groups are also othered in terms of religious practices which are marginalized from the mainstream culture, Muslim. Speaking different languages, practicing different religions, living in remote area and working with less desirable prestige, these cultural representations constitute a marginal positioning about the minority groups.

\subsubsection{Negative Stereotypes Upon Minority Groups}

Although ethnic groups are described as important part of the culture of the country, it seems that the rest content in the textbook is irrelevant to show the actual importance of ethnic groups except revealing the exotic but backward living style.

River gypsies in Bangladesh are having various problems. First, Bangladesh is getting urbanised very rapidly. Gypsy people are losing their customers in urban population. Hence, their income is threatened. Secondly, 24000 kilometres of previous waterways has shrunk into only 6000 kilometres in the country in dry seasons.

Scientists believe that Bangladesh will be worst affected by global climate change. The unpredictable rain and drying out of rivers have made boat movement heavily restricted. Thirdly, many river gypsies are changing their lifestyle in the context of changed reality. They are thinking of living permanently on land. The authority feels that river gypsies need help to survive in the mainstream population. Therefore, the government is offering voting rights, permanent housing and bank-loan facilities. However, changes do not come overnight.

Traditionally, river gypsies are used to water life. They have inherited from their forefathers necessary life skills to survive in waters. They have no education and training to adapt to mainstream modern society. So the authority feels the need to bring them under formal education network. But they have no permanent living place. Gypsy children are born and brought up on roaming boats. Therefore, they cannot go to conventional schools. And hence, mobile boat-schools are coming up for gypsy children. Some voluntary organisations are running special schools on boats to educate river gypsy children in some areas.

Excerpt 10. River gypsies' problems (English for Today,

\section{Class 8, P. 86)}

River gypsies, as one of ethnic groups in Bangladesh, are depicted as different cultural practices by using the third person plural forms "their". For example, river gypsies people spend a nomadic life style "floating" from here and there. It is noted that the way their different life is constructed as social problem causing environmental problem and bringing shame to the modernization of Bangladesh. In fact, many ethnic minority groups like river gypsies have been struggling to have their identity recognized by Bangladesh since its national independence in 1971 [12]. Despite paying lip-service to bridge the social differences between river gypsies and the mainstream society of Bangladesh, we argue that such cultural representation of seeing their life style as backward, lack of education and unurbanized de facto reproduce the hierarchies and social injustice.

\section{Discussion}

The quantitative results in section 4.1 reveal that the number of Bangladeshi and foreign characters are quite imbalanced. Regarding the distribution of source and foreign characters, Bangladeshi characters include almost all kinds of occupations while only a few occupations are depicted among foreign characters, thus resulting in oversimplification of foreign characters. In addition, these textbooks provide limited ethnicities and nationalities, that is, white/Anglophone characters are dominant in the identity options.

The qualitative results concerning on the ideological representations in section 4.2 shows:

1) Speaking Bangla as national glorify is contradictory to the dominance and high values of English represented in the textbooks. In English for Today series used in junior secondary level, Bangla language with historic Language Movement is quite highlighted and speaking national language is national identity and glory. However, English is reproduced and constructed as the most powerful language due to its highly-valued capital. English is a necessity for travelling outside Bangladesh, the only lingua franca for global communication, and a panacea getting good jobs. English in Bangladesh is dominant due to historic reason of British colonization and widely use for social demands in modern society.

2 ) In the four textbooks, there is oversimplification and imbalance in the representations of foreign culture, that is, British-oriented or Anglophone-centered knowledge in Bangladesh English education. Although there are several foreign characters from other English-speaking countries, the majority of foreign characters is white British. In addition, representations of foreign culture are confined within English poems and stories written by British poets. And Oxford English dictionary is shown in the textbooks to exemplify the best English learning belonging to British domain.

3) It seems that women in the textbooks are positively constructed to gain rising status. However, this rising in the world is unexpectedly treated as a victim under the 
rapid economic development. Economy is one of factors to get rid of poverty. As it is shown in introduction part of this study, Bangladesh has transformed from being one of the poorest countries in South Asia to an aspiring "tiger" economy. This economic transformation was driven by its success of manufacturing industry which provides employment for more than 2.2 million people especially women. That's why women have opportunities to gain money because of domestic demand to national economic development in the globalised world. But women in fact are commonly treated as cheap labours. They are victims of fake liberation with the veil of economic globalisation.

4) The esstentialised and dominant Bengali culture in the textbooks is highlighted while cultures of ethnic groups are marginalised and devalued. In Bangladesh, the majority population is Bengali. The culture of Bengalis is highlighted in the textbooks like Bengali folk songs, musical instruments and traditional quilt and even Bangla language. The cultural diversity of Bangladesh is tended to be erased because the representations of other ethnic groups cultures are oversimplified. In the textbooks, the diversified ethnic groups of Bangladesh are generally introduced to language learners. Only a reading passage and images are adopted to depict the cultures of a number of ethnic groups. An ethnic group, River Gypsies is constructed as unstable and uncivilised people living in the society. They bring many problems to the Bangladesh government. So when Bengali culture is highlighted, the ethnic groups are simplified and devalued.

\section{Conclusion}

This study evaluates Bangladeshi English language textbooks, English for Today used from Class Six to Ten in Junior Secondary level. Foreign language textbooks play an important role in shaping learners' awareness of cultural diversity and ideological orientation. This study evaluates four English textbooks English for Today for Bangladeshi students of Junior Secondary level from Class Six to Class Ten. Data were collected from images, reading passages and dialogues of the textbooks. Following the theory of language ideology, the study examines the identity options and ideological representations in the English textbooks. Findings indicate that there are two different communities constructed by Bangladeshi characters and foreign characters in terms of gender, occupation, ethnicity and nationality; findings reveal that the identity option of Bangladeshi characters is diverse ranging from upper/middle class to low class whereas foreign characters are exclusively constructed as white/Anglophone holding decent jobs and having middle class background. Findings also show that the cultural representation of Bangladesh is dominated by the linguistic nationalism of speaking Bangla and following Bangladeshi practices as cultural norm while othering and even stigmatizing minority cultures. When representing foreign cultural practices,
British-centered knowledge is produced as norm and Anglophones as ideal English speakers, and English is constructed as panacea for getting good jobs and communicating with people worldwide. Based on the findings, we argue that the white/Anglophone-centered ideology and homogenous representation of Bangladeshi culture are the reproduction of hierarchical differences structured in the postcolonial regiment. We also argue that highlighting Bangladeshi women's social achievement and minimizing the representation of Muslim practices are mediated in the wider process of socioeconomic transformation of turning Bangladesh into a world factory with sufficient human resources and little religious disturbance.

This study has implications for designing foreign language textbooks and it suggests that more diversified practices from source and foreign cultures should be included in the textbooks to cultivate learners' cultural awareness and appreciation of cultural differences on an equal basis.

This study is subject to several limitations. For English for Today series used in secondary level, there are still Class 11 and 12 textbooks in Higher Secondary education. The in-depth analysis is limited to the Junior Secondary Level from Class 6 to 10. In the future, it would be advisable to examine more textbooks for various fields of English learning. At the same time, English for Today series is taught in Bangladesh public schools. There are still other English language textbooks used in private schools which are to be explored in future research. Moreover, findings in this study are confined within evaluation of textbooks in terms of identity options and ideological representations. There will be a gap between textbooks analysis and real society. These aspects like the actual status of Bangladeshi males and females, the use of English language in daily life in relation to the current employment in Bangladesh are not able to be covered and discussed in textbooks analysis. The future study is therefore recommended to explore how language learners' exposure to the textbooks might shape or influence their intercultural communication within Bangladesh and cross the border.

\section{Acknowledgements}

This work was supported by Yunnan University under the Grant [No. 18YNUGSP015] and [No. 18YNUGSP051] and funded by the College of Foreign Languages of Yunnan University under the Grant [C176210301].

\section{References}

[1] Absar, S. (2001). Problems Surrounding Wages: The Ready-made Garment Sector in Bangladesh. Labour and Management in Development Journal, 2 (7), 20-35.

[2] Alshammri, A. (2017). Evaluating the Representations of Identity Options and Cultural Elements in English Language Textbooks used in Saudi Arabia (master thesis). Macquarie University, Sydney, Australia. 
[3] Ali, T. (2008). WTO Rules and the Ready-made Garment Industry of Bangladesh. Seminar Paper organised by East West University. Dhaka: BGMEA.

[4] Alimorad, Z. (2014). Examining Identity Options in Native and Nonnative Produced Textbooks Taught in Iran: A Critical Textbook Evaluation. RALs, 5 (2), 97-107.

[5] Ali, M. (2014). An Evaluation of English for Today: For Classes 11-12 as a Textbook for Bangladesh Higher Secondary Education (HSE). The English Teacher, 63 (1), 5-8.

[6] Apple, M. W. (1990). Ideology and curriculum (2nd ed.). London: Routledge.

[7] Basu, K. (2018). This is what you need to know about Bangladesh's remarkable economic rise. World Economic Forum. Retrieved from http://weforum.org/why-Bangladesh-booming.

[8] Bradley, N. (2018) Essentialism in the Concept of Culture: Gauging Belief. Journal of Intercultural Communication, 21, $1-21$.

[9] Braun, V. \& Clarke, V. (2006). Using thematic analysis in psychology. Qualitative Research in Psychology, 3, 77-101.

[10] Clarke, V. \& Braun, V. (2013) Teaching thematic analysis: Overcoming challenges and developing strategies for effective learning. The Psychologist, 26 (2), 120-123.

[11] Canagarajah, S. (1993). American textbooks and Tamil students: Discerning ideological tensions in the ESL classrooms. Language, Culture, and Curriculum, 6, 143-156.

[12] Chakma, N. \& Maitrot, M. (2016). How ethnic minorities became poor and stay poor in Bangladesh. Working Paper. Retrieved from http://www.shiree.org/wp-content/uploads.

[13] Fairclough, N. (1995). Critical discourse analysis: The critical study of language. London: Longman.

[14] Frankenberg, F. (1993). White women, race matters: the social construction of whiteness. Minneapolis: University of Minnesota Press.

[15] Government of Bangladesh. (1972). The constitution of Bangladesh. Dhaka: Author.

[16] Gu, M., \& Patkin, J. (2013). Heritage and identity: Ethnic minority students from South Asia in Hong Kong. Linguistics and Education, 24 (2), 131-141.

[17] Hamid, M. (2016). English-in-Education Policy and Planning in Bangladesh: A Critical Examination. Research Gate, 10 (2), 27-30.

[18] Hani, U., \& Siddika, M. (2018). The Application of English Textbook in HSC level: A Case Study in Bangladesh. American Journal of Humanities and Social Sciences, 6 (1), 4-10.

[19] Hall, S. (1996). The question of cultural identity. Modernity: An introduction to modern societies. Cambridge: MA: Blackwell.

[20] Holsti, O. R. (1969). Content analysis for the social sciences and humanities. MA: Addison-Wesley.

[21] Jin, L., \& Cortazzi, M. (2002). English language teaching in China: A bridge to the future. Asia-Pacific Journal of Education, 22 (2), 53-64.
[22] Kaur, P. (2014). Accent attitudes: Reactions to English as a lingua franca. Procedia-Social and Behavioral Sciences, 134, $3-12$.

[23] Kroskrity, P. V. 2004. Language ideologies. A companion to linguistic anthropology, ed. A. Duranti, 496-517. Malden, MA: Blackwell.

[24] Li, J. (2017). Social Reproduction and migrant education: a critical sociolinguistic ethnography of Myanmar students' learning experiences at a border high school in China. (PhD), Macquarie University, Sydney.

[25] Liu J. (2010). Bangladesh. Beijing: Social Sciences Academic Press.

[26] Lippi-Green, R. (2012). English with an accent: Language, ideology, and discrimination in the United States (2nd ed.). London, UK: Routledge.

[27] Ministry of Education. (2010). National education policy 2010 (Final). Dhaka: Government of the People's Republic of Bangladesh.

[28] Mohamed, M. A. S. (2014). The representation of the Orient in English language textbooks used in Libyan secondary schools (Doctoral dissertation, University of Sheffield). Retrieved from http://etheses.whiterose.ac.uk.

[29] Ma, Q. P. (2011) Cultural Representations in Primary English Language Textbooks in China (Master thesis). Nangyang Technological University, Nangyang, China.

[30] Maguire, M. \& Delahunt, B. (2017). Doing a Thematic Analysis: A Practical, Step-by-Step Guide for Learning and Teaching Scholars. AISHE-J, 8, 3352-3360.

[31] Majanen, S. (2008). English as a Lingua Franca: Teachers' Discourses on Accent and Identity (MA thesis), University of Helsinki, Helsinki, Finland.

[32] Mckay, S. L., \& Bokhorst-Heng, W. D. (2008). International English for its sociolinguistic contexts. New York/London: Routledge.

[33] Mottaleb, K. (2011). An Inquiry into the Rapid Growth of Garment Industry in Bangladesh. GRIPS Discussion Paper.

[34] Otlowski, M. (2003). Ethnic diversity and gender bias in EFL textbooks. Asian EFL Journal, 5 (2). Retrieved from the World Wide Web: http://www.asian-efl-journal.com/june_2003_mo.php.

[35] Piller, I. (2015). The International Encyclopedia of Language and Social Interaction. John Wiley \& Sons, Inc.

[36] Piller, I. (2016). Linguistic Diversity and Social Justice. New York and Oxford: Oxford University Press.

[37] Porreca, K. L. (1984). Sexism in current ESL textbooks. TESOL Quarterly, 18 (4), 705-724.

[38] Poulou, S. (1997). Sexism in the discourse roles of textbook dialogues. Language Learning Journal, 15, 68-73.

[39] Pedwell, C. (2010). Feminism, culture and embodied practice: The rhetorics of comparison. Abingdon: Routledge.

[40] Phillips, A. (2010). What's wrong with essentialism? Distinktion: Scandina Journal of Social Theory, 11 (1), 47-60. 
[41] Rahman, T. (2010). A multilingual language-in-education policy for indigenous minorities in Bangladesh: challenges and possibilities. Current Issues in Language Planning, 11 (4), 341.

[42] Rhodes, M., \& Tworek, M. (2012). Cultural transmission of social essentialism. Proceedings of the National Academy of Sciences.

[43] Sahragard, R., \& Davatgarzadeh, G. (2010). The representation of Social Actors in Interchange Third Edition series: A critical discourse analysis. The Journal of Teaching Language Skills, 2 (1), 67-89.

[44] Shohamy, E. (2006). Language Policy: Hidden agendas and new approaches. London and New York: Routledge.

[45] Shardakova, M., \& Pavlenko, A. (2004). Identity options in Russian textbooks. Journal of Language, Identity, and Education, 3 (1), 25-46.

[46] Shahiduzzaman, E. (2010). Repression against Women on Rise in Bangladesh. New Age Newspaper. 25 November.

[47] Siddiqi, A. (2004). The Ready-made Garment Industry of Bangladesh. Dhaka: Dhaka University Press.
[48] Siegal, M., \& Okamoto, S. (1996). Imagined worlds: Language, gender, and socio-cultural "norms" in Japanese language textbooks. Gender and belief systems. Proceedings of the Fourth Berkeley Women and Language Conference, April 1921, 1996 (pp. 667-678). Berkeley: University of California, BWLG.

[49] Silverstein, M. 1979. Language structure and linguistic ideology. In The elements: A parasession on linguistic units and levels, ed. P. Clyne, R. W. F. Hanks, and C. Hofbauer, 193-247. Chicago: University of Chicago.

[50] Söylemez, A. S. (2010). A study on how social gender identity is constructed in EFL course books. Procedia-Social and Behavioral Sciences, 9, 747-752.

[51] Tador, C. T. \& Polzer, J. T. (2013). Not just for stereotyping anymore: racial essentialism reduces domain-general creativity. Psychological Science, 24 (1), 99-105.

[52] Yunus, M. \& Yamagata, T. (2012). The Garment Industry of Bangladesh. Experience of Asia and Africa (Intertrim Report), $2-10$. 